\title{
УДОСКОНАЛЕННЯ ВИМІРІВ РІВНЯ ПАЛИВА ПРИ АВТОМАТИЗОВАНОМУ КОНТРОЛІ ЙОГО ВИТРАТИ
}

\author{
Представив д-р техн. наук, професор О.Б. Бабанін
}

\begin{abstract}
Постановка проблеми у загальному вигляді, іiі зв'язок 3 важливими науковими та практичними завданнями. У цей час витрати на енергетичні ресурси, які забезпечують роботу рухомого складу залізниць, є однією 3 найбільш значних статей витрат залізничної галузі. Ощадливу витрату паливно-енергетичних ресурсів при експлуатації тепловозів неможливо реалізувати без об'єктивного й технологічно обгрунтованого процесу обліку й контролю витрати палива. Один 3 напрямків щодо забезпечення ефективності обліку, контролю й аналізу витрати палива тепловозами пов'язаний 3 автоматизацією процесів виміру й реєстрації параметрів роботи локомотива, застосуванням сучасних засобів виміру витрати палива.
\end{abstract}

Аналіз останніх досліджень i публікацій. Питанню автоматизації процесу обліку й контролю за витратою палива присвячений ряд досліджень [1-5 і iн]. У них автори акцентували увагу як на теоретичних основах створення інформаційно-контролюючих комплексів у системі керування локомотивним господарством, так i на практичних результатах реалізації їхньго поетапного використання. Розроблено й знаходять застосування ряд сучасних систем контролю й обліку витрати палива $[3,4,6]$, що включають у себе паливновимірювальну систему, бортову підсистему виміру, а також стаціонарну підсистему обробки й аналізу зафіксованих показників. Контроль кількості палива (в основному на маневрових тепловозах) здійснюється за рівнем палива в баку тепловоза, обмірюваним у протилежних кінцях паливного бака. Як показали дослідження, на ефективності використання автоматизованого контролю позначається відсутність у деяких системах синхронізування даних про витрату палива 3 режимами роботи дизеля, неврахування температури й пов'язаного 3 нею коректування щільності дизельного палива. На точність вимірів впливає розташування датчиків на баку, їхній тип, а також особливості конструкції паливних ємностей. Особливої уваги вимагає облік впливу нахилу бака на похибку виконуваних операцій, тим більше, що в ряді тепловозів $є$ можливість установити на баку тільки один датчик контролю рівня палива.

Мета дослідження. Метою даної роботи $\epsilon$ дослідження й розроблення методичного підходу для вирішення важливого науково-практичного завдання створення ефективної й економічної системи виміру фактичної витрати палива.

Основна частина. Однією 3 важливих умов успішного застосування автоматизованих систем контролю полягає в їхній інваріантності до типів тепловозів і можливості уніфікації на основі аналізу конструкції паливних баків i їx контролепридатності. Під контролепридатністю в цьому випадку розуміється можливість встановлення спеціальних пристроїв контролю кількості палива.

Маючи безумовні загальні компонувально-технологічні особливості (у всіх тепловозів паливні баки розташовуються між візками під рамою 
локомотивів і являють собою зварені зі сталевих листів ємності), конструкційно вони досить різні. Це можна бачити на поданих ескізах у таблиці основних характеристик паливних баків сучасних тепловозів. Крім того, як показує практика, паливні баки тепловозів однієї серії можуть істотно відрізнятися один від одного.
Паливні баки тепловозів 3 несучими кузовами (ТЕП70) є елементом конструкції головної рами й виготовляються одночасно 3 нею. У більшості випадків баки кріпляться до рами твердим або напівтвердим кріпленням. У баках деяких тепловозів улаштовуються ніші для розміщення допоміжного устаткування тепловозів.

Таблиця

Конструктивні розміри паливних баків сучасних тепловозів

\begin{tabular}{|c|c|c|c|c|c|c|}
\hline \multirow{2}{*}{$\begin{array}{c}\text { Серія } \\
\text { тепловоза }\end{array}$} & \multirow{2}{*}{$\begin{array}{c}\text { Поперечний } \\
\text { перетин } \\
\text { паливного бака }\end{array}$} & \multicolumn{3}{|c|}{ Конструктивні розміри, мм } & \multirow{2}{*}{$\begin{array}{c}\text { Теоретична } \\
\text { ємність, л }\end{array}$} & \multirow{2}{*}{$\begin{array}{c}\text { Невжива- } \\
\text { ний об'єм, } \\
\text { л } \\
\end{array}$} \\
\hline & & довжина & ширина & висота & & \\
\hline 2TE116 & & 3665 & 3080 & 926 & 7860 & 200 \\
\hline 2TE10M & & 3060 & 2626 & 1040 & 7300 & \\
\hline 2M62 & & 2928 & 2500 & 930 & 3950 & 200 \\
\hline ТЕП70 & & 5040 & 2690 & 910 & 8000 & 360 \\
\hline ТЕП150 & & 3470 & 2760 & 1001 & 5560 & 750 \\
\hline ЧME3 & & 3100 & 2000 & 1060 & 6000 & 500 \\
\hline TEM103 & & 3180 & 2485 & 975 & 5000 & 400 \\
\hline
\end{tabular}

Іноді за умовами компонування тепловоза паливний бак виконують із декількох окремих відсіків, з'єднаних між собою трубами, наприклад, на тепловозі ТГМ6А бак складається із двох частин, на тепловозі ТГМЗА - три об'єднані паливні ємності.

Як видно 3 таблиці, габаритні обмеження по висоті і ширині паливних баків обумовлюють невеликий діапазон зміни даних параметрів (від 2690 до
3180 мм по ширині і від 910 до 1060 мм по висоті), тоді як значення довжини, визначені в значній мірі розмірами бази тепловоза і базою візків, відрізняються більш істотно (від 2000 до 4850 мм). Місткості баків коливаються від 3950 л (тепловоз М62) до 8000 л (тепловоз ТЕП70). Вельми значним є також діапазон зміни місткості баків в 1 мм перетину по висоті $\left(3,3-9,6\right.$ дм³ $^{3}$ мм). Такий діапазон пояснюється також меншими розмірами 
баків у нижній третині, обмеженій габаритом рухомого складу, неоднорідністю поздовжнього перетину баків по висоті, наявністю внутрішніх поздовжніх i поперечних перегородок 3 отворами для сполучення порожнин утворених ними відсіків бака, наявністю внутрішніх відсіків, не призначених для зберігання основного запасу палива (об'єми для брудного палива, відсіки акумуляторних батарей). У зв'язку 3 цим градуйовані характеристики баків $\epsilon$ нелінійними.

Згідно 3 [7], вимір обсягу дизельного палива в баку тепловоза виконують на прямій горизонтальній ділянці шляху. Однак при роботі маневрових тепловозів зміна машиністів, при якій обов'язковий вимір кількості палива, нерідко відбувається на станції. Відповідно до ПТЕ, станції можуть розташовуватися на ухилах не крутіше 0,0025 (у важких умовах), а підйом головки рейки однієї 3 ниток вища над іншою в прямій ділянці шляху допускається до 6 мм.

При здійсненні безперервного контролю витрати палива в процесі експлуатації локомотивів можуть мати місце й більш істотні перепади рівнів i нахилів. Так, для тепловоза ЧМЕ3 при ухилі колії в $20 \%$ різниця висот крайніх передньої й задньої точок бака складе 40 мм, а при максимальному завищенні зовнішньої рейки в кривій (150 мм) різниця висот крайніх лівої й правої точок бака досягатиме 286 мм.

У цьому випадку обсяг палива в баку тепловоза може бути визначений за формулою

$$
\mathrm{V}=\mathrm{V}_{\mathrm{o}}\left(1 \pm \frac{\mathrm{L}_{\text {Д }}}{\mathrm{H}_{\mathrm{o}}} \operatorname{tg} \alpha\right),
$$

де $\mathrm{V}_{\mathrm{o}}$ i $\mathrm{H}_{\mathrm{o}}$ - відповідно обмірювані обсяг $\mathrm{i}$ висота дизельного палива;

$\mathrm{L}_{д}$ - відстань від геометричного центра бака до датчика рівня;

$\alpha$ - кут нахилу паливного бака в поперечному напрямку до його поздовжньої осі.

Відповідно до [8] масу витраченого палива за робочу зміну, поїздку або поїзну операцію можна визначити формулою:

$$
\begin{aligned}
\mathrm{m} & =\mathrm{m}_{\mathrm{i}}-\mathrm{m}_{\mathrm{i}+1}=\mathrm{V}_{\mathrm{i}}\left(1+2 \gamma \delta_{t i C T}\right) \rho_{i}\left(1+\beta \delta_{\mathrm{ti}}\right)\left(1 \pm \frac{\mathrm{L}}{\mathrm{H}_{\mathrm{i}}} \operatorname{tg} \alpha_{i}\right)- \\
& -\mathrm{V}_{\mathrm{i}+1}\left(1+2 \gamma \delta_{\mathrm{t}(\mathrm{i}+1) \mathrm{CT}}\right) \rho_{\mathrm{i}+1}\left(1+\beta \delta_{\mathrm{t}(\mathrm{i}+1)}\right)\left(1 \pm \frac{\mathrm{L}}{\mathrm{H}_{\mathrm{i}+1}} \operatorname{tg} \alpha_{i+1}\right)
\end{aligned}
$$

де $V_{i}, V_{i+1}$ - обсяги дизельного палива відповідно на початку й кінці фіксованого періоду часу, обумовлені за градуйованою таблицею паливного бака, м $^{3}$;

$\rho_{\mathrm{i}}, \rho_{\mathrm{i}+1}-$ середні щільності дизельного палива відповідно на початку й кінці контрольної операції, кг/ $\mathrm{M}^{3}$;

$\gamma$ - коефіцієнт лінійного розширення матеріалу стінок паливного бака, $1 /{ }^{\circ} \mathrm{C}$;

$$
\delta_{t C T}=\left(t_{V}-t_{\Gamma P}\right) "-\text { різниця температур }
$$
стінок паливного бака при вимірі обсягу $\left(t_{V}\right)$ і при градуюванні $\left(t_{\Gamma P}\right),{ }^{\circ} \mathrm{C}$; $\beta$ - коефіцієнт об'ємного розширення дизельного палива, $1 /{ }^{\circ} \mathrm{C}$;

$\delta_{t}=\left(t_{\rho}-t_{V}\right)-$ різниця температур дизельного палива при вимірі щільності $\left(\mathrm{t}_{\rho}\right)$ i обсягу $\left(\mathrm{t}_{\mathrm{V}}\right),{ }^{\circ} \mathrm{C}$.

Отримана формула справедлива для діапазону рівнів палива, обумовленого таким виразом:

$$
\mathrm{H}_{\min }+\operatorname{Ltg} \alpha_{\max }<\mathrm{H}_{\mathrm{B}}<\mathrm{H}_{\max }-\operatorname{Ltg} \alpha_{\max },
$$

де $\mathrm{H}_{\min }, \mathrm{H}_{\max }$ - відповідно мінімальний $\mathrm{i}$ максимальний рівень палива; 
$\alpha_{\max }-$ максимальний кут нахилу паливного бака.

Конструктивні особливості

тепловозних паливних баків дозволяють забезпечувати вірогідність вимірів рівня палива в межах певних діапазонів. Для тепловозу 2TE116 рівень палива в баку має бути в межах від 118 мм до 822 мм. Оскільки на практиці паливний бак повністю не заповнюється й мінімальна кількість палива в баку не повинна бути менше 500 кг, то наявні обмеження не позначаються на здійсненні необхідних вимірів.

При проведенні вимірів витрати палива в умовах змінного кута нахилу бака необхідною операцією $є$ обчислення значень реального рівня $\mathrm{H}_{\mathrm{i}}$. Обчислення реального рівня палива в умовах змінного кута нахилу бака можливе з використанням рівняння взаємозв'язку, що являє собою функцію п'яти змінних $\mathrm{H}_{\mathrm{i}}=\mathrm{f}\left(\mathrm{H}_{\mathrm{b}}, \mathrm{L}_{\mathrm{5}}, \mathrm{H}_{\text {д }}, \mathrm{L}_{\text {Д, }}\right.$, а). При цьому параметри $\mathrm{H}_{\mathrm{b}}, \mathrm{L}_{\mathrm{5}}, \mathrm{i} \mathrm{L}_{\text {д }}$ установлюються при уведенні системи виміру витрати палива в експлуатацію, а $\mathrm{H}_{\text {д }}$ i $\alpha \in$ динамічно змінюваними в процесі вимірів.

Оскільки кут нахилу $\alpha$ не перевищує $6^{\circ}$, то для оцінки похибки виміру витрати палива можна покласти, що $\operatorname{tg} \alpha \approx \alpha$. Тоді модель похибки визначення витрати дизельного палива буде описуватися таким виразом:

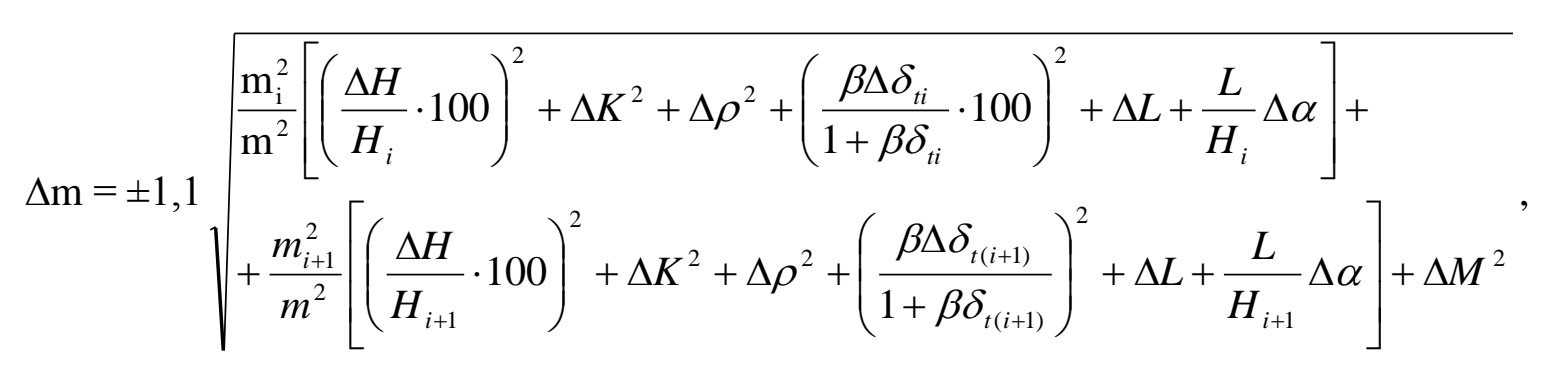

де $\mathrm{H}$ - рівень продукту в ємності, м;

$\Delta \mathrm{H}$ - абсолютна похибка виміру рівня наповнення продукту, м;

$\Delta K$ - відносна похибка градуювання резервуара, \%; $\%$;

$\Delta \rho$ - відносна похибка виміру щільності,

$\Delta M$ - відносна похибка центрального блока обробки й індикації даних, \%.

Встановлено, що в результаті нахилу відбувається перерозподіл палива по обсягу бака й рівень палива в точці виміру змінюється, при цьому обсяг палива залишається незмінним. Таким чином, виникає похибка обчислення обсягу $\Delta \mathrm{V}$ за обмірюваним значенням рівня $\mathrm{H}_{\mathrm{i}}$. Компенсація зазначеної похибки є визначальним чинником при розробленні методики обчислення витрати палива 3 використанням рівнемірів.
Висновки 3 дослідження i перспективи, подальший розвиток $\mathbf{y}$ даному напрямку. Проведено аналіз конструкцій паливних баків тепловозів різних серій, що дозволило сформулювати вимоги до вимірювальних засобів автоматизованої системи контролю в частині корегування значень реальних i визначення граничних рівнів вимірів. Зазначено, що похибка виміру реального рівня дизельного палива залежить від геометричних розмірів баку. При цьому, чим менше значення відношення висоти бака до його довжини, тим більше значення похибки. Похибка виміру реального рівня залежить також від ступеня заповнення бака паливом. При цьому значення похибки збільшується, якщо в баку незначна кількість палива або коли він заповнений практично повністю. 


\section{Список літератури}

1. Жуховицький, I.B. Проблеми та перспективи автоматизації управління локомотивним господарством [Текст] / І.В. Жуковицький, О.Б. Устенко, О.Л. Зіненко // Інформаціно-керуючі системи на залізничному транспорті. - 2009. - № 2. - С 38-42.

2. Тимченко, А.Ю. Подходы к созданию единой автоматизированной системы учета дизельного топлива в ОАО «РЖД» [Текст] / А.Ю. Тимченко, А.А. Троицкий // Локомотивинформ. - 2008. - № 6. - С. 26-28.

3. Автоматизированная система учета, контроля и анализа расхода топлива маневровыми тепловозами [Текст] / А.И. Молчанов, И.Л. Поварков, Л.А.Мугинштейн, К.М. Попов // Вестник ВНИШКТ. - 2004. - № 2. - С. 25 - 29.

4. Тартаковський, Е.Д. Технічні та технологічні засоби енергозбереження тепловозів в експлуатації [Текст] / Е.Д. Тартаковський, М.Г. Уманець, Д.О. Аулін // Вісник СУНУ ім. В. Даля. - 2010. - Вип. 5 (143). -Ч. 2. - С. 215-219.

5. Белецкий, Ю.В. Системы конроля топливной экономичности [Текст] / Ю.В. Белецкий, Н.М. Найш, Ю.Е. Калабухин // Вісник СНУ ім В.Даля. - 2010. - С. 27-29.

6. Дробаха, В.І. Результаты практичного впровадження систем «БІС-Р» [Текст] / В.І. Дробаха, О.Д. Трихліб, А.М. Каплун // Локомотив-информ. - 2007. - № 9.- С. 24-25.

7. Инструкция о порядке и методах измерений при учетных операциях с нефтепродуктами на предприятиях федерального железнодорожного транспорта №10865. [Текст]. - Утв. 10.06.2010. - М.: МПС России, 2010. - 16 с.

8. ГОСТ 26976-86. Нефть и нефтепродукты. Методы измерения массы. - М.: Комитет стандартизации и метрологии СССР. $-1986 .-14$ с.

Ключові слова: облік, автоматизовані системи контролю, дизельне паливо,фактична витрата, паливний бак, похибка виміру.

\section{Анотаціi}

У статті проведений аналіз конструкцій паливних баків тепловозів різних серій, що дозволило сформулювати вимоги до вимірювальних засобів автоматизованої системи контролю в частині коректування значень реальних і визначення граничних рівнів вимірів.

В статье проведен анализ конструкций топливных баков тепловозов различных серий, что позволило сформулировать требования к измерительным средствам автоматизированной системы контроля в части корректировки значений реальных и определения предельных уровней замеров.

An analysis of constructions of fuel tanks of diesel engines of different series is conducted In article, that allowed to formulate the requirements to the measuring facilities of the automated checking system in parts of adjustment of values real and determinations of maximum levels of measuring. 